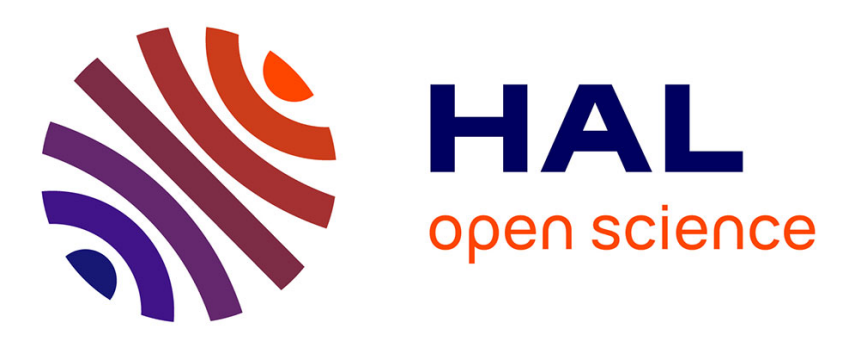

\title{
Food Supply Chain - Sustainability in Small Milk Industry
}

Simone Beux, Arcione Viagi, Roberto Panizzolo, Martino Cassandro, Nina

Waszczynskyj

\section{- To cite this version:}

Simone Beux, Arcione Viagi, Roberto Panizzolo, Martino Cassandro, Nina Waszczynskyj. Food Supply Chain - Sustainability in Small Milk Industry. IFIP International Conference on Advances in Production Management Systems (APMS), Sep 2016, Iguassu Falls, Brazil. pp.598-605, 10.1007/9783-319-51133-7_71. hal-01615784

\section{HAL Id: hal-01615784 \\ https://hal.inria.fr/hal-01615784}

Submitted on 12 Oct 2017

HAL is a multi-disciplinary open access archive for the deposit and dissemination of scientific research documents, whether they are published or not. The documents may come from teaching and research institutions in France or abroad, or from public or private research centers.
L'archive ouverte pluridisciplinaire HAL, est destinée au dépôt et à la diffusion de documents scientifiques de niveau recherche, publiés ou non, émanant des établissements d'enseignement et de recherche français ou étrangers, des laboratoires publics ou privés.

\section{(c)(1)}

Distributed under a Creative Commons Attribution| 4.0 International License 


\title{
Food Supply Chain - Sustainability in Small Milk Industry
}

\author{
Simone Beux*, Arcione Viagi, Roberto Panizzolo, and Martino Cassandro \\ *Federal University of Paraná, Paraná, Brazil \\ beuxsimone@gmail.com
}

\begin{abstract}
Farming is very important for the development of a country economy and, in Brazil, cattle (meat and milk) is one of the most important sectors of this segment. This paper aims to develop a conceptual framework to identify the key characteristics of the Short Food Supply Chain and, moreover, propose a model for the implementation of sustainability in the sector of small milk producers and dairy products. The research presents data from small producers located in Paraná, Brazil and utilizes the better condition of Italian producers in the Veneto region as a benchmarking to identify opportunities for improvement by adopting the concept of Short Food Supply Chain. The conclusion of the analysis showed that there are significant gains for small farmers with the adoption of the proposed model because it solves several issues that currently hinder the development of the sector.
\end{abstract}

Keywords: Sustainability $\cdot$ Production $\cdot$ Milk $\cdot$ Supply Chain

\section{Introduction}

Brazil is among the largest producers of milk in the world, ranks sixth, according to data from the United States Department of Agriculture in the year 2014. It produced 35.2 billion liters, increased by $2.7 \%$ compared to 2013 [1]. Milk production in the country is growing, but the challenge will be hard in the coming years in relation to: adequate food for the herds in terms of quantity and quality, improving product quality indicators, business management for efficient use of resources and improving competitiveness for the world market competition. Another major challenge is to resolve issues such as low professionalization of the sector; it is characterized by many small and medium producers in a state of insolvency.

According to data from the last Census of Agriculture in 2006, it was observed that most producers have low production and they are responsible for the majority of national production ( $80 \%$ of farmers produce up to 50 liters/day and account for $26 \%$ of Brazil's milk production). In Paraná, $55.3 \%$ of farmers produce up to 50 liters/day, representing $14.7 \%$ of total production of the state, about $60 \%$ of Paraná's production comes from small family farms. For these reasons, the Federal University of Technology-Paraná (Brazil) and University 
of Padova (Italy), has ongoing projects to technology transfer to improve the performance of producers of milk and dairy products.

The objective of this work is to propose a management model for the supply chain of small farmers and assess their applicability in Brazil. The work has exploratory approach, using case study and benchmarking, with data obtained from available literature and collected through qualitative research with small farmers in the state of Paraná.

This paper is organized into four sections: Section 2 presents the theoretical framework, Section 3 analyze State of Paraná situation and describe the proposed model, and Sections 4 draws the conclusions followed by the references.

\section{Theoretical Framework}

\subsection{Sustainability in Food Industry}

The concern with sustainability is recent (1980) and defines which companies are part of a whole and their activities generate impacts throughout society, so they should get reasonable economic results without destroying nature or creates problems for society today and in the future [2]. In the 1990s, the proposed balance received the designation of triple bottom line (Fig. 1) and advocated that sustainability is achieved when there is a balance between value creation, environmental responsibility and social responsibility $[2,3,4]$.

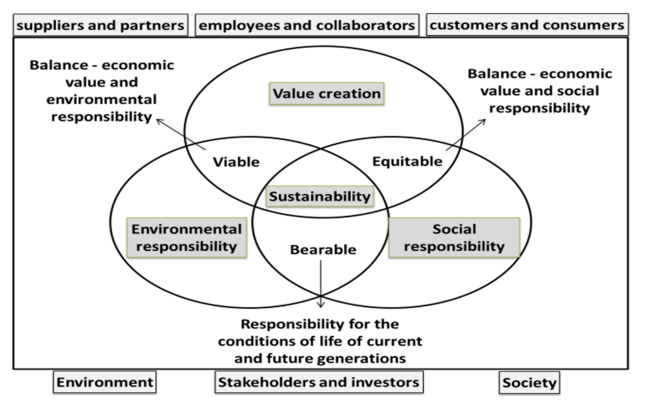

Fig. 1. Triple Bottom Line [2]

The approach for this paper in terms of sustainability is to develop actions that improve the management of small producer of milk and dairy products and increase their profitability.

\subsection{Supply Chain Management in Food Industry}

Growing competition and higher consumer expectations have forced companies to seek alternative forms of management in order to reduce costs and increase 
the quality and availability of products. As a result of this trend, Supply Chain Management (SCM) has been adopted in order to improve the efficiency of operations through increased collaboration between trading partners and greater proximity to customers $[5,6]$. For the adoption of SCM two major problems have been arisen: the first concerns the need for traceability (Fig. 2) of products due to increased consumer attention for safe and animal-friendly production methods, such as the origin and production techniques used. The second is related to the aspect of providing more speed to the process, reducing losses due to food and agricultural products shelf life constraints, therefore alternatives are: to reduce product crossing time in the agrifood chain or to use preserving agent in order to increase products life. This solution has been questioned and rejected by the most demanding consumers [7]. The SCM enables the production and the deliv-

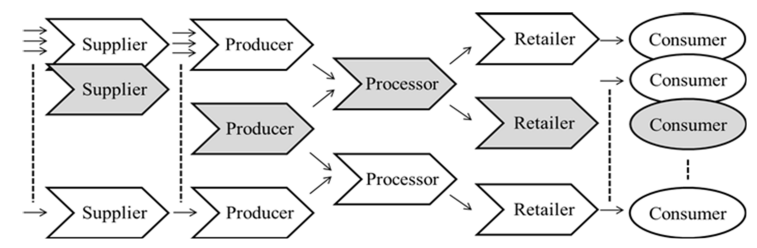

Fig. 2. Supply chain network and specific [6]

ery of food products at competitive prices in all parts of the planet. In a Food Supply Chain (FSC) several companies collaborate strategically in more than one area without losing their own identity and autonomy. In general, the quality assurance of products in the agrifood chain depends on integration, awareness and collaboration of participants in the supply chain because misconduct can compromise the result of all the others [5]. The focus has been produce with sustainable methods and processes, quality products and offers them in the consumption places, at the right time to meet consumer expectations. However, this represents a problem for small producers who not have production volume or financial capacity to be representative in this new competitive regional, national and global market.

Because of the difficulties faced by small producers and their importance in the overall context of the economy, there are a number of actions in several countries, aimed to provide viable alternatives for strengthening the small farmers. One of them is the Short Food Supply Chain (SFSC), (Fig. 3), initially created for the purpose of achieving goals of "sustainable agriculture" by reducing transport costs and, hence, $\mathrm{CO}_{2}$ emissions and promoting biodiversity by strengthening periurban agriculture.

Currently, interest in this alternative has grown and has been incorporated into the Europe Union (EU) scope and has encouraged states members to use this concept in the local markets to strengthen them. Moreover, the EU has considered the key role of small farmers in the food supply chain and provides a credit line to finance projects aimed at the participation of farmers to a "struc- 
tured" short food supply chain, where quality products are linked to territory [8]. The SFSC can be structured in two basic ways always focusing on marketing in the local market or region, ensuring the reduction of transport costs. The first is the vertical integration of a producer and the second is the integration of various agricultural producers, located within walking distance that can process the products and distribute them in the local market or region.

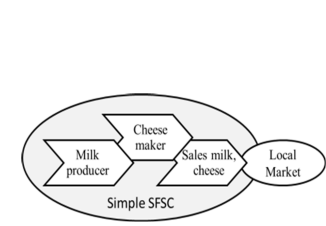

(a) Single SFSC

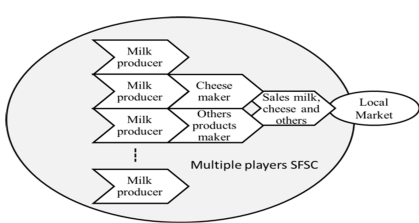

(b) Multiple players SFSC

Fig. 3. Single and Multiple players SFSC

\subsection{Food Supply Chain in Italy}

Italy has a great tradition in the production of dairy products and, therefore, this activity receives great attention from public and private agencies: largest usage of milk is to cheese making [9]. Cheeses have one of the greatest values in milk chain, which contributes to the strengthening of the sector in the country. Even with the strong dairy chain with several positive points, between the small Italian producers, the operating current form is the vertical integration (multifunctional diversification), the milk processing is performed by the producer and marketing through direct sale, in a process known as "short-chain"; it has a direct influence on many weaknesses listed because it strengthens local production and supply chain management (Figure 4).

The economic crisis and the growing desire of consumers for fresh and healthy products had boosted the interest and adoption of the concept of "short chains" in Italy and in the European Union as a whole. In fact, the need to support producer organizations and direct sales, to strengthen the activity, led to one of the objectives of the new Common Agricultural Policy (CAP) [10].

The creation and ongoing operation of SFSC proved to be a highly effective model because farmers or distributors can add value to rural activity by encouraging the production and consumption in the local market. Also, in order to promote local agriculture, the European Union (EU) approved a rule which provides farmers can make the labeling of products for direct sale [8]. The young farmers with higher education have better understanding of this market trend, and they recognize that the consumers prefer to buy regional products due to growing concerns about safety and nutrition of food. Another important initiative is the denomination Small Local Production (SLP) by the "Regional Veneto Council" for the recognition of traditions value [11]. 


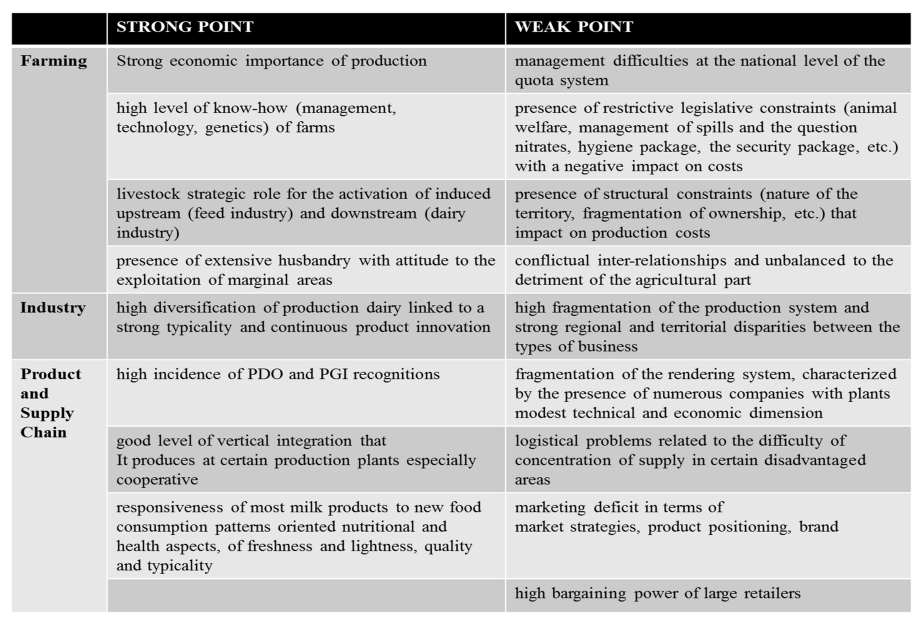

Fig. 4. Strong and weak points of the phase [7]

\section{Analysis of Milk Production in the State of Paraná and SFSC Management Model for Small Producers}

The Brazilian reality is different; the small producers are struggling to maintain activity, because they have no bargaining power with dairies and distributors. In the recent years, public policies stimulate an increasing of milk production and influence the improvement of milk quality, ensuring the standardization of products according to the demand, especially in the dairy industry. But many farmers cannot meet the required standards [12], the worst consequence of this situation is that many farmers become bankrupt or they cannot influence the descendants to continue the activity, creating a rural exodus. One of the strong points in Italy is that farmers have high knowledge of management, technology and genetics while in Brazil, mainly in small properties, there is a deficiency in these areas, resulting in low productivity of herd.

In Brazil, the average production is $950 \mathrm{~kg} / \mathrm{cow} /$ year versus $5.579 \mathrm{~kg} / \mathrm{cow} /$ year in Italy and in state of Paraná, in 2013 milk, production was $2.533 \mathrm{~kg} / \mathrm{cow} /$ year $[13,14]$.The strengthening of the Italian chain is also associated with typical products, as well as high supply of products with Protected Geographical Identification (PGI) and Protected Designation of Origin (PDO). A survey in Europe showed that more than $50 \%$ of consumers recognize the certifications and willing to pay between $10 \%$ and $30 \%$ more [15], in Brazil it is necessary to consolidate and enhance product with these concepts.

Other problems are these collection system due to the distance of the property and aggravated due to the precariousness of the roads [16,17] and small number of laboratories accredited in Paraná, about 18 laboratories [18]. In Italy, considering only the region of Veneto, which has less than $10 \%$ of Paraná size, there are 61 laboratories. Regarding the hygienic-sanitary quality, the Brazil- 
ian normative requires quality standard, but without presenting alternatives to solve the problems, it results in a greater impact on small producers. An alternative to the small farmer is the agribusiness with production of cheeses, yoghurts and others dairy products, adding value to raw materials and providing relative autonomy, however, these several factors hinder this initiative. In this context, after reviewing the data on the current conditions of small farmers agricultural and compare with data considered as benchmark in the industry, it became clear that the evolution of the recent years does not eliminate the gaps between policies and effective practices to ensure the sustainability of Brazilian agribusiness. Figure 5 shows the strengths and weaknesses identified in the exploratory survey answered by farmers in the southwestern state of Paraná region in conjunction with information obtained from related industry literature review. As can be seen, it is already evident big difference in terms of strengths and weaknesses, demonstrating that a few factors have been crucial in maintaining the sector's competitiveness. However, according to Cassandro [19] the add value (AV) for cheese in the southwest of Paraná is satisfying, the production cost (per liter) of milk is around $\$ 0.207$ and the value of cheese produced is $\$ 0.443$, with these values AV generated is positive, $\$ 0.235$, this demonstrates a good opportunity for producers.

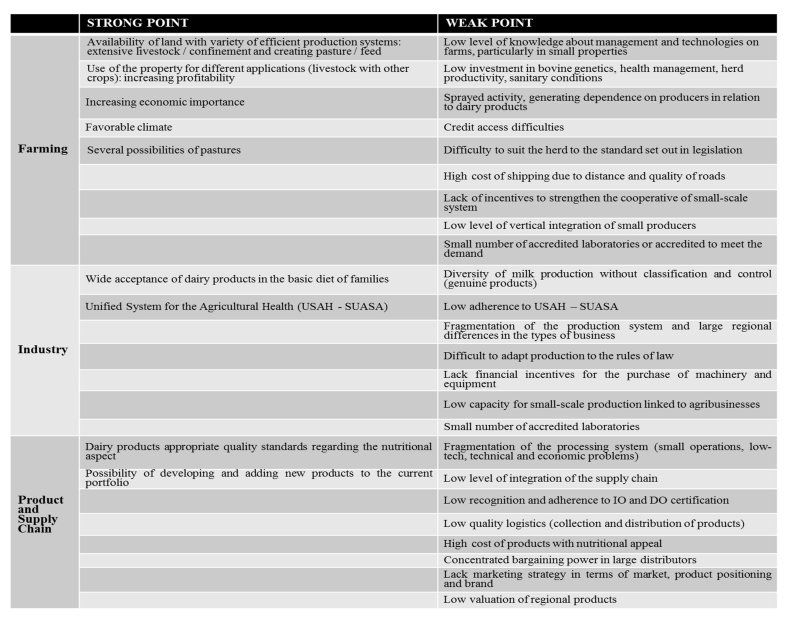

Fig. 5. Strong and weak points: Agriculture, Industry and Product/Supply Chain

Figure 6 shows the steps to implementation SFSC in the approved and promoted manner by the EU and observed operating in Italy. The proposed change is not easy and requires the assessment of priorities before you start it, because the distrust of the entrepreneur disturbs the identification of potential business partners. In Italy, the economic crisis and the lack of jobs for young people have generated the return of many to the agricultural activities of the family. They return with training and willingness to take an innovative approach and this 
has been a success factor and facilitator for the implementation of some public policies to encourage the creation of local SFSC.

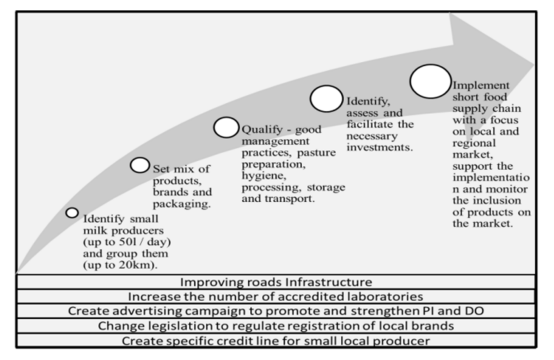

Fig. 6. Main Steps to Implement SFSC

The activities to structure a SFSC are: Choosing the right business partners; Make a logistic map, role of each player and the flow of market information; Define the capacity and bottlenecks; Define service model (push or pull); Define the joint logistics to support the process; Implement an information system and Define how the profits will be shared. As in Italy it is possible applied this systems for small producers in Paraná, and create a structured of the milk SFSC as a sustainable alternative for them.

\section{Conclusions and Outlook}

This work confirmed the problems identified in the literature review as the situation of the Brazilian milk production and the State of Paraná and identified other factors that have contributed negatively to the development of rural family farms in milk production and dairy products sector. It was found that there were significant structural problems whose solution will not be achieved in the short term; in this sense the SFSC for dairy chain can represent a viable alternative for sustainability of small and medium milk producers.

The growing concern about the future of small farmers and the alternatives to become more competitive are considered important to motivate them to accept the proposal. To enable the pilot deployment, the team should be composed of universities (researchers), rural service, trade associations, and industry regulators to give agility, support and structuring. Since this work is just an early effort in the pursuit of competitive advantages for small farmers, new scientific studies could open new opportunities of application of the model through process simulations and case studies.

\section{References}

1. IBGE: Projeção da População do Brasil por Sexo e Idade para o Período 2000/2060. Tech. rep. (2015) 
2. Azapagic, A., Perdan, S.: Indicators of Sustainable Development for Industry. Process Safety and Environmental Protection 78(4), 243-261 (2000)

3. Foran, B., Lenzen, M., Dey, C., Bilek, M.: Integrating Sustainable Chain Management with Triple Bottom Line Accounting. Ecological Economics 52(2), 143-157 (2005)

4. Gimenez, C., Sierra, V., Rodon, J.: Sustainable Operations: Their Impact on the Triple Bottom Line. International Journal of Production Economics 140(1), 149 159 (2012)

5. Rong, A., Akkerman, R., Grunow, M.: An Optimization Approach for Managing Fresh Food Quality Throughout the Supply Chain. International Journal of Production Economics 131(1), 421-429 (2011)

6. Vorst, J.G.A.J.v.d., Da Silva, C.A., Trienekens, J.H.: Agro-industrial Supply Chain Management: Concepts and Applications. FAO, Rome (2007)

7. D'Alessio, M.: Filiera Latiero-casearia: Caratteri Strutturali e Andamenti Congiunturali. Economia della produzione 17, 15-24 (2014)

8. Canfora, I.: Is the Short Food Supply Chain an Efficient Solution for Sustainability in Food Market? Agriculture and Agricultural Science Procedia 8, 402-407 (2016)

9. Cassandro, M.: Comparing Local and Cosmopolitan Cattle Breeds on Added Values for Milk and Cheese Production and their Predicted Methane Emissions. Animal Genetic Resources 53, 129-134 (2013)

10. De Fazio, M.: Agriculture and Sustainability of the Welfare: The Role of the Short Supply Chain. Agriculture and Agricultural Science Procedia 8, 461-466 (2016)

11. Morgan, K., Marsden, T., Murdoch, J.: Worlds of Food: Place, Power, and Provenance in the Food Chain. Oxford geographical and environmental studies, Oxford University Press, Oxford; New York (2006)

12. Schmitz, A.M., Santos, R.A.: A Produção de Leite na Agricultura Familiar do Sudoeste do Paraná e a Participação das Mulheres no Processo Produtivo. Terra Plural 7(2), 339-356 (2014)

13. DERAL, D.d.E.R.: Analise da Conjuntura Agropecuária. Tech. rep., Departamento de Economia Rural, Curitiba (2013), http://www.agricultura.pr.gov.br

14. Júnior, G., Santos, E.B.: Evolução da Produção de Leite no Brasil. Revista Veterinária e Zootecnia 20 (2013)

15. Kakuta, S.M., Souza, A., Schwanke, F.H., Giesbrecht, H.O.: Indicações Geográficas: Guia de Respostas. Porto Alegre: Sebrae/RS p. 38 (2006)

16. Paixão, M.G., Domingo, E.C., Gajo, A.A., Torres, L.M., Abreu, L.R., Pinto, S.M.: Carretagem de Leite a Granel: Um Estudo de Caso. Revista do Instituto de Laticínios Cândido Tostes 66(382), 42-47 (2011)

17. Zoccal, R., Dusi, G.A.: Modelo Ideal para Produção de Leite no Brasil. Tech. Rep. Animal Business-Brasil, Sociedade Nacional da Agricultura, Passo Fundo (2013)

18. INMETRO, I.N.d.M.Q.e.T.: Inmetro - Consulta ao Catálogo da RBLE (2016), http://www.inmetro.gov.br/laboratorios/rble/

19. Cassandro, M.: Sustainable Milk Production in Different Dairy Cattle Systems and Valorisation of Environmental Chain on the Basis of Added Value. Poljoprivreda 21(1), 22-27 (2015) 